\title{
COVID-19: Ivermectin; Molecular Mechanisms, Limitations, Suggestions
}

\author{
CoviD-19: Ivermektin; Moleküler Mekanizmalar, Sınırlılıklar, Öneriler
}

\author{
(i) Mustafa KESMEN1,2, iD Ceren ANLAŞ2, iD Tülay BAKIREL22, id Eray Metin GÜLER³
}

${ }^{1}$ İstanbul Pendik Veterinary Control Institute, Drug Quality Control Laboratory, İstanbul, Turkey

${ }^{2}$ İstanbul University Cerrahpaşa Faculty of Veterinary Medicine, Department of Pharmacology and Toxicology, İstanbul, Turkey

${ }^{3}$ Bezmialem Vakıf University Faculty of Medicine, Department of Medical Biochemistry, İstanbul, Turkey

\begin{abstract}
To date, no effective treatment has been found against coronaviruses $(\mathrm{CoVs})$, which have re-emerged with severe acute respiratory syndrome CoV-2 (SARS-CoV-2) and have a high potential for disease in humans as well as domestic and wild animal species. The investigation of treatment options to combat this virus, which has a pandemic character with its high morbidity and mortality rate, is a multidisciplinary research subject. In this context, the drug repositioning has come to the agenda in the fight against SARS$\mathrm{CoV}-2$, which is the current subject. However, despite the superior characteristics of drug options other than rational usage purposes such as easy accessibility and rapid transfer to the field, the lack of evaluations for their efficacy and safety may lead to misleading. In this review, the applicability, risks, and possible molecular mechanisms of ivermectin, which is suggested to be an effective treatment option, are discussed within the framework of the pharmacokinetic and toxicokinetic properties of the drug.
\end{abstract}

Keywords: Antiviral efficacy, COVID-19, drug repurposing, ivermectin, SARS-CoV-2

\section{ÖZ}

Şiddetli akut solunum sendromu koronavirüs-2 (SARS-CoV-2) ile yeniden gündeme gelen, evcil ve yabani hayvan türlerinin yanı sıra insanlarda da hastalık yapabilme potansiyeli yüksek olan CoV karşı günümüze değin etkin bir tedavi yöntemi bulunamamıştır. Yüksek morbidite ve mortalite oranı ile pandemik bir karakter kazanan bu virüsle mücadele amacıyla tedavi seçeneklerinin araştırılması multidisipliner bir araştırma konusudur. Bu kapsamda, güncel konu niteliğinde olan SARS-CoV-2 ile mücadelede ilaçların yeniden konumlandırma çalışmaları gündeme gelmiştir. Ancak rasyonel kullanım amaçlarının dışındaki ilaç seçeneklerinin, kolay ulaşılabilirlik ve hızla uygulamaya aktarılabilir olmaları gibi üstün özelliklerine rağmen, etkinlik ve güvenilirliklerine yönelik değerlendirmelerin yapılmamış olması yanlış yönlendirmelere yol açabilmektedir. Bu derlemede, etkin bir sağaltım seçeneği olabileceği ileri sürülen ivermektinin SARS-CoV-2 tedavisinde kullanılabilirliği, riskleri ve olası moleküler mekanizmalar, ilacın farmakokinetik ve toksikokinetik özellikleri çerçevesinde ele alınmıştır.

Anahtar Sözcükler: Antiviral etkinlik, COVID-19, ilaç yeniden konumlandırma, ivermektin, SARS-CoV-2

\section{Introduction}

Coronaviruses are single-stranded, large positive-polar RNA (having the largest genome of all RNA viruses), belonging to the order of Nidovirales.
In humans, they cause respiratory tract and gastrointestinal system infections, in addition to these, mostly mild, self-healing, and rarely with severe respiratory failure and renal involvement fatal diseases. In some animal species (rats, mice, various bird species, ruminants, dogs, cats, rabbits, pigs, etc.) they cause respiratory diseases or gastroenteritis $(1,2)$. 
Viruses belonging to the coronavirus family that are effective on humans and animals was first defined as infectious bronchitis virus in poultries in 1937, and the first human coronavirus was reported in the 1960s. The coronavirus, which has the potential to pass from animals to humans and to cause epidemics by mutation. There are 7 different coronavirus species, which infections in humans, these are CoV 229E, $\mathrm{HCoV} N L 63, \mathrm{HCoV}$ HKU1 and HCoV OC43, and in addition to these, SARS-CoV, Middle East respiratory syndrome (MERS) and SARS-CoV-2 $(3,4)$. A new member of this family of viruses was identified for the first time in Wuhan, China in December 2019 and was defined as SARS-CoV-2 due to its genetic association with the virus that caused the SARS epidemic, and the disease it caused is named as by the World Health Organization as coronavirus disease (COVID-19) $(5,6)$.

With the scope of combating this virus, which is classified as a pandemic and has become a threat to all humanity, research on vaccine development and treatment still continues, but no effective specific agent has yet been found for the treatment of coronaviruses. This situation has led to the importance of drug repositioning studies, which include the use of known drugs for new purposes, in the treatment of COVID-19 (7-10).

Current studies carried out in this context have revealed the approach that ivermectin, a compound widely used in veterinary practice for the control of parasitic infections, can be effective in the treatment of COVID-19. Ivermectin, a broad spectrum antiparasitic compound approved by the US Food and Drug Administration (FDA), is known to exhibit antiviral activity against many viruses in vitro. Similarly, in a study conducted in a SARS-CoV-2 infected Vero/hSLAM cell line, it was reported that an approximately 5,000-fold decrease in viral RNA was detected at the $48^{\text {th }}$ hour following ivermectin administration at $5 \mu \mathrm{M}$ concentration (11). According to the findings, the researchers stated that ivermectin has in vitro antiviral activity against SARS-CoV-2 and this effect is likely to occur by blocking the nuclear entry of importin alpha and beta-1 (IMP $\alpha / \beta 1)$ mediated viral protein (11). Since the application of ivermectin yielded remarkable results against SARS-CoV-2, clinical studies based on the use of ivermectin + nitazoxanide combination as an adjuvant to hydroxychloroquine and azithromycin were initiated (12). In contrast, the FDA reported that such in vitro research is widely conducted in the early stages of drug development studies, but more research is needed on whether ivermectin is effective and safe in preventing or treating coronavirus or COVID-19 (13). When the ivermectin effectiveness in COVID-19 treatment is evaluated in relation to the pharmacokinetic profile of the drug; whenever the $5 \mu \mathrm{M}$ concentration found effective in in vitro conditions adapted to in vivo conditions, the highest peak plasma concentration reached was $247.8 \mathrm{ng} / \mathrm{mL}$, and this concentration was used after the approved dose $(150-200 \mu \mathrm{g} / \mathrm{kg})$ to reach the plasma peak concentration $(30-47 \mathrm{ng} / \mathrm{mL})$ approximately 17 times $(14,15)$.

There are many studies evaluating the antiviral activity of ivermectin in vitro conditions. In a study carried out by Wagstaff et al (16), it was reported that ivermectin is an inhibitor of
IMP $\alpha / \beta 1$ mediated nuclear import and prevents the replication of human immunodeficiency virus (HIV-1) by inhibiting the entry of viral proteins into the nucleus. There are also studies confirming that ivermectin is effective against Porcine Reproductive and Respiratory Syndrome Virus (17), Bovine Herpes Virus (18), Newcastle Disease Virus (19), Chikungunya Virus, Semliki Forest Virus and Sindbis Viruses (20).

In the study evaluating the activities of some molecules including ivermectin against Dengue Virus (DENV), it was reported that the in vitro activity test was terminated due to the high cytotoxic effect of ivermectin in the HuH-7 cell line (21). On the other hand, in a study conducted in vitro with liposome formulation of ivermectin, it was reported that the cytotoxic effect of the drug decreased up to 5 times, and the antiviral $\mathrm{EC}_{50}$ value against DENV 2 reached from $2.6 \mu \mathrm{M}$ to $0.3 \mu \mathrm{M}$ (22). In studies conducted at known therapeutic doses, ivermectin inhibit Pseudorabies Virus (23) in BHK-21 cell line and mice, Porcine Circovirus 2 (24) in PK-15 cell line and piglets. Ivermectin has a wide safety margin with no adverse effects up to 50 times the recommended dose in pigs (25). Remarkable findings were also obtained in studies evaluating the effectiveness of ivermectin against Flaviviruses. It has the highest potency for Yellow Fever Virus, which causes hemorrhagic fever, with an $\mathrm{EC}_{50}$ value of $0.5 \mathrm{nM}$. It has also proven to be a micromolar level replication inhibitor for DENV, West Nile Virus, Japanese Encephalitis Virus and Tick-borne Encephalitis Virus in in vitro studies (26). As a result of the application made to the World Intellectual Property Organization, it has been observed that the use of all Avermectins and Milbemicins in the treatment of Flavivirus infections is protected by patent (27).

There are many veterinary medicinal products around the world where this first endectoside, which is widely used in veterinary treatment with its powerful anthelmintic, insecticide and acaricidal effects, is included as an active ingredient $(28,29)$. In our country, different pharmaceutical forms of ivermectins, whose marketing authorization has been issued by the Ministry of Agriculture and Forestry, General Directorate of Food and Control, has an indication area for cattle, sheep, horses and dogs (30). 1\% cream form has been found by American and European authorities to be more effective and safe than known treatment options for the treatment of rose disease lesions with inflammatory lesions, known as Rosacea, and has been approved for human use (31).

There are also studies evaluating the antiviral activity of ivermectin as well as its anti-inflammatory and antitumoral activity. It has been shown that avermectin used in inflammation induced by lipopolysaccharide inhibits Tumor necrosis factor-alpha (TNF- $\alpha$ ) and interleukin (IL)- $1 \beta$ production significantly and increases IL-10 production in macrophages. These effects were reported to be mediated by ERK1/2, JNK and p38 MAPK signal and activation of the NF-KB pathway (32).

Ivermectin also show antitumoral activity by effecting the MDR protein inhibition, Akt/mTOR pathway inhibition, PAK1 protein inhibition, WNT-TCF pathway inhibition, SIN3 
domain inhibition, NS3 DDX23 helicase inhibition, Nanog/ Sox2/Oct4 genes downregulation, activation of P2X 4/P2X and increased chlorine channel mechanisms (33).

Another effect of ivermectin is related to P-glycoprotein (P-gp). It has been observed that when the P-gp substrate ivermectin is used in combination with the P-gp inhibitor Verapamil, it can cause cytogenetic and teratogenic effects in rats (34). Similarly, when mice lacking the gene encoding P-gp (MDR1a -/-) were treated with the standard antiparasitic protocol of ivermectin, the concentration of ivermectin in brain tissue was found to be 100-fold higher than wild-type mice, and death was reported. Neurotoxic effects and hypersensitivity reactions associated with mutation in P-gp genes were observed in subpopulations of CF1 mice and coli dogs (35). In addition, since ivermectin acts as a $\mathrm{Na}^{+}, \mathrm{K}^{+}$-ATPase inhibitor at a dose of 6-17 $\mu \mathrm{M} \mathrm{IC}_{50}$, it has been reported that this situation indicates significant adverse effects when used at high doses (36).

There are controversial results in studies examining the genotoxicity potential of ivermectin. In this context; Ames test using Salmonella typhimurium and Salmonella typhimurium + S9, in vitro L5178Y/TK +/- mouse lymphoma assay, in vitro unprogrammed DNA synthesis in human fibroblasts, in vitro sister chromatid exchange in peripheral human lymphocytes and $\mathrm{CHO}-\mathrm{K} 1$ cells in vitro in rat thymocyte It has been reported that apoptosis induction gives negative results. On the other hand, in relation to ivermectin, in vitro comet test, mitotic index, cell cycle progression, neutral red, MTT test results (37-39) and in vitro sister chromatid exchange test in peripheral human lymphocytes (40) were positively detected in $\mathrm{CHO}-\mathrm{K} 1$ cells. Similarly, in their in vivo studies; according to the chromosomal aberration test and micronucleus test findings, they concluded that ivermectin has clastogenic and genotoxic potential in mice (41). In another study, in which the genotoxicity potential of ivermectin was evaluated with the comet test system in Zebu cattle, it was stated that the concentrations of $1 \%$ and $3.15 \%$ of the compound caused a significant DNA damage and may show genotoxic potential (42). As part of drug repositioning, a network of medicine framework has been developed over the past decade, consisting of a set of quantitative approaches and predictive tools to examine host-pathogen interactions, uncover the molecular mechanisms of infections, identify comorbidities, and quickly identify drug candidates. Gysi et al. (43), published the results that shows the drugs that may affect biological processes targeted by the virus by using in vitro data. In this context, it has been suggested that clinical trials of ivermectin, whose toxicity and side effects are known, should be started rapidly (43).

Studies that involve repositioning drugs, requiring less time to target with a low cost advantage, may potentially not require preclinical trials and may enter phase 2 studies directly. Combination therapy strategies can be developed that may delay or reduce resistance associated with monotherapy, thanks to known mechanisms of action. Candidate drug analogs are easily available for testing. Researchers and small-scale laboratories can be the determinant of drug positioning processes, not requiring initial investment thanks to large-scale formulation and production chains. However, due to the high doses used in in silico screening studies, toxic drugs may be initially identified as active, unforeseen and undesirable side effects may be encountered, and the effective plasma concentration may be much higher than the levels achievable for humans $(44,45)$.

\section{Suggestions}

In silico screening and in vitro researches are of great importance in drug development and repositioning studies. However, as with the controversy over ivermectin, the clinical pharmacokinetics of studies in in vitro conditions should be carefully evaluated when adapted to in vivo conditions.

Ivermectin, and its derivatives are protected by patent for some indications. In the efforts to reposition the drugs that are easily accessible in the world that meet the priority needs of the population, patent protection research may be useful due to the obstacles to the public accessibility of patented substances and products.

Quality assurance systems, and good cell culture practices gain importance in terms of reliability and reproducibility of research, and it is considered important that these principles are adapted to applications by researchers. In this context, it would be useful to investigate the effectiveness of ivermectin comprehensively by different researchers.

In addition to supporting the data obtained under in vitro conditions with in vivo research, it is thought that it may be beneficial to carry out formulation development studies to increase bioavailability and reduce undesirable effects.

Peer-review: Internally peer reviewed.

\section{Authorship Contributions}

Concept: M.K., C.A., T.B., E.M.G., Design: M.K., C.A., T.B., Data Collection or Processing: M.K., C.A., T.B., E.M.G., Analysis or Interpretation: M.K., C.A., T.B., E.M.G., Literature Search: M.K., C.A., T.B., E.M.G., Writing: M.K., C.A., T.B.,

Conflict of Interest: No conflict of interest was declared by the authors.

Financial Disclosure: The authors declared that this study received no financial support.

\section{References}

1. İnal S. Middle East Respiratory Syndrome-Coronavirus (MERSCoV) Enfeksiyonu: Okmeydanı Tip Dergisi 2016;32(Ek sayı):37-45.

2. Microbiology Book Online, Viroloji Bölüm 25, Koronavirüsler, Soğuk Algınlığı ve SARS, Availeble from: https://www.microbiologybook. org/Turkish-virology/virolchapter25turk.htm

3. TÜBİTAK, Bilim ve Teknik Dergisi, Küresel Kabus, Availeble from: https:/tubitak.gov.tr/sites/default/files/18842/bilim_ve_teknik_ coronavirus_hakkinda.pdf

4. Hasöksüz M, Kiliç S, Saraç F. Coronaviruses and SARS-COV-2. Turkish Journal of Medical Sciences. https://doi.org/10.3906/sag2004-127. 
5. International Committee on Taxonomy of Viruses (ICTV), Naming the 2019 Coronavirus 2020. Availeble from: https://talk.ictvonline. org/

6. World Health Organisation, Naming the coronavirus disease (COVID-19) and the virus that causes it, 2020. Availeble from: https:/www.who.int/emergencies/diseases/novel-coronavirus-2019/ technical-guidance/naming-the-coronavirus-disease-(covid-2019)and-the-virus-that-causes-it

7. Pushpakom S, Iorio F, Eyers PA, Escott KJ, Hopper S, Wells A, et al. Drug repurposing: Progress, challenges and recommendations. Içinde Nat Rev Drug Discov 2018;1:41-58.

8. Information for Clinicians on Investigational Therapeutics for Patients with COVID-19 2020. Available from: https://www.cdc. gov/coronavirus/2019-ncov/hcp/therapeutic-options.html

9. T.C. Sağlık Bakanlığı COVID-19 (SARS-CoV-2 ENFEKSIYYONU) REHBERİ 2020. Available from: https://covid19bilgi.saglik.gov.tr/ depo/rehberler/COVID-19_Rehberi.pdf?type=file

10. World Health Organisation Off-label use of medicines for COVID-19 2020. Available from: https://www.who.int/news-room/ commentaries/detail/off-label-use-of-medicines-for-covid-19

11. Caly L, Druce JD, Catton MG, Jans DA, Wagstaff KM. The FDAapproved drug ivermectin inhibits the replication of SARS-CoV-2 in vitro. Antiviral Res 2020;178:104787. https://doi.org/10.1016/j. antiviral.2020.104787

12. U.S.National Institute of Health, Clinical Trials, 2020. Available from: https:// clinicaltrials. gov/ct $2 /$ results? cond= COVID\&term= ivermectin $\&$ cntry $=\&$ state $=\&$ city $=\&$ dist $=\&$ Search $=$ Search

13. U.S. Food and Drug Administration, Letter to Stakeholder, 2020, Available from: https://www.fda.gov/animal-veterinary/productsafety-information/fda-letter-stakeholders-do-not-use-ivermectinintended-animals-treatment-covid-19-humans

14. Bray M, Rayner C, Noël F, Jans D, Wagstaff K. Ivermectin and COVID-19: a report in Antiviral Research, widespread interest, an FDA warning, two letters to the editor and the authors' responses. Antiviral Res 2020;178:104805. https://doi.org/10.1016/j. antiviral.2020.104805

15. Momekov G, Momekova D. Ivermectin as a potential COVID-19 treatment from the pharmacokinetic point of view. medRxiv 2020.04.11.20061804. https://doi. org/10.1101/2020.04.11.20061804

16. Wagstaff K, Rawlinson S, Hearps A, Jans D. Novel Inhibitors of Nuclear Translocation of HIV-1 Integrase. Antiviral Res 2011;90:A48. https://doi.org/10.1016/j.antiviral.2011.03.081

17. Lee YJ, Lee C. Ivermectin inhibits porcine reproductive and respiratory syndrome virus in cultured porcine alveolar macrophages. Arch Virol 2016;161:257-68.

18. Raza S, Shahin F, Zhai W, Li H, Alvisi G, et al. Ivermectin inhibits bovine herpesvirus 1 DNA polymerase nuclear import and interferes with viral replication. Microorganisms 2020;8:1-15.

19. Azeem S, Ashraf M, Rasheed MA, Anjum AA, Hameed. Evaluation of cytotoxicity and antiviral activity of ivermectin against Newcastle disease virus. Pak J Pharm Sci 2015;28:597-602.
20. Varghese FS, Kaukinen P, Gläsker S, Bespalov M, Hanski L, Wennerberg. Discovery of berberine, abamectin and ivermectin as antivirals against chikungunya and other alphaviruses. Antiviral Res 2016;126:117-24.

21. Chu JJH, Lee RCH, Ang MJY, Wang WL, Lim HA, Wee JLK, et al. Antiviral activities of 15 dengue NS2B-NS3 protease inhibitors using a human cell-based viral quantification assay. Antiviral Res 2015;118:68-74.

22. Croci R, Bottaro E, Chan KWK, Watanabe S, Pezzullo M, Mastrangelo E, et al. Liposomal Systems as Nanocarriers for the Antiviral Agent Ivermectin. Int J Biomater 2016. https://doi. org/10.1155/2016/8043983

23. Lv C, Liu W, Wang B, Dang R, Qiu L, Ren J, et al. Ivermectin inhibits DNA polymerase UL42 of pseudorabies virus entrance into the nucleus and proliferation of the virus in vitro and vivo. Antiviral Res 2018;159:55-62.

24. Wang X, Lv C, Ji X, Wang B, Qiu L, Yang Z. Ivermectin treatment inhibits the replication of Porcine circovirus 2 (PCV2) in vitro and mitigates the impact of viral infection in piglets. Virus Res 2019;263:80-6.

25. Sanford SE, Rehmtulla AJ, Josephson GKA. Ivermectin overdose and toxicosis in neonatal pigs. Can Vet J 1998;29:735-36.

26. Mastrangelo E, Pezzullo M, De burghgraeve T, Kaptein S, Pastorino $\mathrm{B}$, Dallmeier K, et al. Ivermectin is a potent inhibitor of flavivirus replication specifically targeting NS3 helicase activity: New prospects for an old drug. J Antimicrob Chemother 2012;67:1884-94.

27. World Intellectul Property Organisation (WIPO). 2020. WO2011051159 - Avermectıns and milbemycins for the treatment of flavivirus infections. Available from: https://patentscope.wipo.int/ search/en/detail.jsf?docId = WO2011051159\&recNum=29\&docAn= EP2010065880\&queryString=DORAMECTIN\&maxRec $=452$

28. U.S.Food And Drug Administration (FDA), (2018). Available from: https://animaldrugsatfda.fda.gov/adafda/views/\#/search

29. European Medicines Agency (EMA), (2018). Available from: http:// www.eudrapharm.eu/eudrapharm/searchbykeywordresult.do

30. Tarım ve Orman Bakanlığı, (2020). Ruhsatlı Veteriner Tıbbi Ürünler, Available from: https://vtu.tarim.gov.tr/FYerli.aspx.

31. Crump A. Ivermectin: Enigmatic multifaceted "wonder" drug continues to surprise and exceed expectations. J Antibiot (Tokyo) 2017;70:495-505.

32. Ci X, Li H, Yu Q, Zhang X, Yu L, Chen N, et al. Avermectin exerts anti-inflammatory effect by downregulating the nuclear transcription factor kappa-B and mitogen-activated protein kinase activation pathway. Fund Clin Pharmacol 2009;23:449-55.

33. Juarez M, Schcolnik-Cabrera A, Dueñas-Gonzalez A. The multitargeted drug ivermectin: from an antiparasitic agent to a repositioned cancer drug. Am J Cancer Res 2018;8:317-31.

34. El-Ashmawy IM, El-Nahas AF, Bayad AE. Teratogenic and cytogenetic effects of ivermectin and its interaction with P-glycoprotein inhibitor. Res Vet Sci 2011;90:116-23.

35. Schinkel AH, Smit JJ, Van Tellingen O, Beijnen JH, Wagenaar E, Van Deemter L, et al. Disruption of the mouse mdrla P-glycoprotein 
gene leads to a deficiency in the blood-brain barrier and to increased sensitivity to drugs. Cell 1994;77:491-502.

36. Pimenta PHC, Silva CLM, Noel F. Ivermectin is a nonselective inhibitor of mammalian P-type ATPases. Naunyn-Schmiedeberg's Arch Pharmacol 2010;381:147-52.

37. EMA, (2004). Committee For Medicinal Products For Veterinary Use EMEA/MRL/915/04-Final Ivermectin (Modification of Maximum Residue Limits) Summary Report (5).

38. Molinari G, Soloneski S, Reigosa MA, Larramendy ML. In vitro genotoxic and cytotoxic effects of ivermectin and its formulation ivomec $^{\bullet}$ on Chinese hamster ovary (CHOK1) cells. J Hazard Mater 2009; 165:1074-82.

39. Molinari G, Soloneski, S, Larramendy ML. New ventures in the genotoxic and cytotoxic effects of macrocyclic lactones, Abamectin and Ivermectin. Cytogenet Genome Res 2010;128:37-45.

40. Aleksić N, Barjaktarović N. Investigation on sister chromatid exchange (SCE) by ivermectin. Genetika 1993;25:219-25.
41. Sweify KM, Abd I, Darwish EM, Demerdash D, El A, Hafez M. The cytogenetic potential of ivermectin on bone marrow cells of mice in vivo. OSR-JESTFT, 2015;9:2319-99.

42. Montes V, De La Ossa VJ, Pérez Cordero A. Comet assay to determine genetic damage by the use of ivermectin in zebu cows ( Bos taurus indicus ). Revista MVZ Córdoba 2017;22:5959-65.

43. Gysi DM, Do Valle I, Zitnik M, Ameli A, Gan X, Varol O, et al. Network Medicine Framework for Identifying Drug Repurposing Opportunities for COVID-19. ArXiv 2020;arXiv:2004.07229v1. Preprint.

44. Mercorelli B, Palù G, Loregian A. Drug Repurposing for Viral Infectious Diseases: How Far Are We? Trends Microbiol 2018;26:86576.

45. García-Serradilla M, Risco C, Pacheco B. Drug repurposing for new, efficient, broad spectrum antivirals. Virus Res 2019;264:22-31. 